\title{
AWARENESS AS A CRITERION OF LEGALITY OF OBTAINING THE PATIENT'S CONSENT TO MEDICAL INTERVENTION
}

Pishchita AN $\bowtie$, Alekseev VA, Borisov KN

Russian Medical Academy of Continuing Professional Education of the Ministry of Health of the Russian Federation, Moscow, Russia.

\begin{abstract}
The doctrine of patient consent to medical intervention, as a compulsory procedure, emerged in the forties of the twentieth century. However, up until the present the problem of obtaining patient consent cannot be considered conclusively resolved. One of the intervention legality criteria is the patient's complete (sufficient) awareness of the proposed medical intervention.
\end{abstract}

Keywords: patient rights, informed voluntary consent of the patient, medical intervention, right to personal integrity, patient awareness, complete (sufficient) information, duties of medical professionals.

Author contribution: Pishchita AN, Alekseev VA — contribution to the concept, analysis of legislation, Borisov KN — contribution to the concept, editing.

$\checkmark$ Correspondence should be addressed: Alexander N. Pishchita

Barrikadnaya st., 2/1, b. 1, Moscow; alexpischita@mail.ru

Received: 26.02.2021 Accepted: 26.03.2021 Published online: 30.03.2021

DOI: $10.24075 /$ medet.2021.006

\section{ИНФОРМИРОВАННОСТЬ КАК КРИТЕРИЙ ЗАКОННОСТИ ПОЛУЧЕНИЯ СОГЛАСИЯ ПАЦИЕНТА НА МЕДИЦИНСКОЕ ВМЕШАТЕЛЬСТВО}

\author{
А. Н. Пищита $\bowtie$, В. А. Алексеев, К. Н. Борисов
}

Российская медицинская академия непрерывного профессионального образования Министерства здравоохранения Российской Федерации, Москва, Россия

Доктрина обязательного получения согласия пациента на медицинское вмешательство возникла в сороковые годы двадцатого века, однако, до сих пор проблему регламента получения согласия пациента нельзя отнести к категории окончательно решенной. Одним из критериев легитимности выполнения вмешательства является полная (достаточная) информированность пациента о предлагаемом медицинском вмешательстве, рисках и осложнениях при его выполнении. Кроме того, расширение прав граждан, получающих медицинскую помощь, в рамах Федерального закона от 21 ноября 2011 г. N 323-Ф3 “Об основах охраны здоровья граждан в Российской Федерации», а так же распространение норм федеральных законов, защищающих права граждан, как потребителей услуг и работ, на пациентов существенно повышает требования к работе медицинских работников, в обязанности которых входит неукоснительное соблюдение прав пациентов.

Ключевые слова: права пациента, информированное добровольное согласие пациента, медицинское вмешательство, право на личную неприкосновенность, информированность пациента, полная (достаточная) информация, обязанности медицинских работников.

Вклад авторов: Пищита А. Н., Алексеев В. А. — вклад в концепцию, анализ законодательства, Борисов К. Н. — вклад в концепцию, редактирование.

Для корреспонденции: Пищита Александр Николаевич

ул. Баррикадная, д. 2/1, стр. 1, г. Москва, 125993; alexpischita@mail.ru

Статья получена: 26.02.2021 Статья принята к печати: 26.03.2021 Опубликована онлайн: 30.03.2021

DOI: 10.24075/medet.2021.006

Awareness is one of the fundamental criteria backing the patient's right to give or refuse consent to medical intervention. The legal requirement to inform the patient primarily covers the following:

- risks of unfavorable development of the disease (condition) in case the patient refuses medical intervention;

- risks of development of complications associated with the medical intervention necessitated by the patient's condition (disease).

It is awareness that allows the patient to compare the risks of adverse development of the disease and the probable (described in the literature) complications associated with the intervention that may arise both during such an intervention, immediately thereafter or later.

The first document to formalize the basic principles of sufficient awareness of a person participating in the study was the Nuremberg Code of 1947, the international code governing human experiments. The code states that a study participant should have sufficient knowledge and understand the essence of the information presented, these knowledge and understanding enabling the participant to make the participation decision while clearly seeing the purpose of the research effort and the associated risks the participants are exposed to.

Before being asked for a well-informed decision, the candidate participant should receive information about:
- duration and purpose of the study;

- means and methods applied;

- the expected inconveniences and probable harm to the participant's health associated with the study;

- negative consequences for the participant's mental and physical health that can, with a certain degree of probability, be a result of participation in the experiment.

After the Nuremberg trials, the concept of "informed consent" is systematically used in European and US courts in the context of medical malpractice cases involving compensation for harm caused through inappropriate provision of medical care.

Around 1950s, the information doctors provided to the patients was of a purely professional (medical) nature, but in the 1970s, there was introduced the patient-oriented approach, which prescribed presenting information in the form the patient can comprehend, with the mandatory components thereof as follows:

- treatment purpose description,

- possible risks,

- existing alternative treatments.

Subsequently, the provisions of the first clause of the Nuremberg Code, which determine the amount and nature of information mandatorily provided to a candidate study participant, were substantially extended. They found 
application not only in the context of lawsuits pertaining to harm caused in the course of clinical trials, but also in litigations about compensations for harm caused through improper provision of medical care.

In 1997, Article 5 of the Convention on Human Rights and Biomedicine stipulated that not only clinical trials, but also medical interventions require free, awareness-based informed consent given by the person offered such interventions.

Upfront, such a person should be provided with appropriate information about the purpose and nature of the proposed intervention, its possible consequences and risks associated therewith [1].

In Russia, the doctor's duty to obtain "the patient's consent" was first formalized on December 1, 1924, when the National Central Executive Committee and the Council of People's Commissars of the RSFSR enacted the Decree "On professional activity and rights of medical workers" [2]. However, this document required obtaining consent only before surgery. Declaration of the Rights and Freedoms of Man and Citizen adopted by the Supreme Soviet of the RSFSR in 1991, the Constitution of the Russian Federation, Fundamentals of the Legislation of the Russian Federation on Health Protection, the Russian Federation Law "On Transplantation", the Russian Federation Law "On psychiatric care and citizen rights guarantees in the context of its provision", as well as a number of other legislative acts adopted in the 1990s, have significantly expanded the personal inviolability rights of citizens (including personal information protection rights) in the context of applying for medical assistance, including:

- the right to informed voluntary consent to medical intervention (Article 32 of the Fundamentals of the Legislation of the Russian Federation on Health Protection);

- the right to refuse medical intervention (Article 33 of the Fundamentals of the Legislation of the Russian Federation on Health Protection);

- the right to receive information about the person's health in an accessible form, including information about examination results, presence of the disease, diagnosis and prognosis, treatment methods, the associated risk, medical intervention options, consequences thereof and treatment results (Article 31 of the Fundamentals of the Legislation of the Russian Federation on Health Protection) [3].

The definition of the "patient's informed voluntary consent" was adopted in the Russian legislation for the first time ever. This definition reflects the patient's right to make an independent, awareness-based decision to give consent or refuse medical intervention.

The Federal Law 323-FZ "On Basics of Health Protection of the Citizens in the Russian Federation" (passed in 2011) entitles the patient to receive full information from a medical professional, this information enabling the patient to make a decision on granting consent to the proposed medical intervention.

Although the definition of "informed voluntary consent" has not changed, it is only since 2012 that people seeking medical assistance at medical institutions have the right to make a decision on allowing a medical intervention once they are in possession of all the relevant information.

Any medical intervention that affects physical, mental, social components of a person's life can take place only after the person such intervention is offered to gives free, informed consent for this specific certain medical intervention.

There is an innovation in the legislative regulation of realization of the citizens' right to personal inviolability in the context of medical care: on the one hand, the law entitles the patient to all the information a medical institution has about health (diseases, complications) of this person;

on the other hand, the law obligates medical workers to fully inform the patient deciding whether to consent to or refuse medical intervention, the information provided enabling the patient to make the important decision.

Following is the review of the order observed by the subjects of medical relations (legal aspects thereof) as they exercise their duly formalized rights and fulfill obligations having to do with the need to provide information to the patient before obtaining his/ her consent to the medical intervention.

Article 20 of the Federal Law "On Basics of Health Protection of the Citizens in the Russian Federation" lists the information that a medical professional must provide to a patient before obtaining his/her consent to medical intervention.

The informed voluntary consent of a citizen is a necessary prerequisite for medical intervention. The consent can be given by the patient personally or by his/her legal representative; the decision relies on the information provided by the medical professional (in full and in an accessible form):

- about the goals, methods of provision of medical assistance, the associated risk,

- about the possible medical intervention options, consequences thereof, and

- about the expected results of medical assistance [4].

Besides, the patient is entitled to get the following information from the medical institution in the comprehensible form:

- about the state of his/her health, including information about the results of a medical examination, presence of the disease, diagnosis and prognosis,

- about the methods of provision of medical assistance, the associated risk,

- about the possible medical intervention types, consequences thereof, and

- about the results of medical assistance [5].

A medical institution, represented by the attending physician, is also obliged to:

- inform citizens about the possibility of receiving medical care under the state program guaranteeing free provision of medical care to citizens and territorial state-guaranteed programs stipulating free medical assistance to citizens;

- provide patients with reliable information about the medical care provided, the effectiveness of treatment methods, drugs and medical devices used;

- using communication patterns/channels accessible to the citizenry, including websites, inform people about medical activities and medical professionals, level of their education and qualifications, as well as provide other necessary information as prescribed by the rulings of the authorized federal executive body;

- inform patients of the order of gratuitous provision of medical assistance as guaranteed by the state program, the scope thereof and conditions applicable thereto [6].

In addition, the attending physician, when recommending the patient a drug, a medical device, foods for special medical purposes or a breast milk substitute, shall inform the patient about how he/she can obtain such a drug, medical device, foods for special medical purposes or a breast milk substitute free of charge, as per provisions of the legislation of the Russian Federation [7]. Apart from Federal Law 323, there are other federal regulations that govern medical professionals' responsibility to provide patients with information. In particular, there are consumer protection laws that apply to the cases of provision of medical assistance by medical institutions under voluntary and compulsory health insurance policies [8]. 
Article 8 of the Russian Federation Law "On Protection of Consumer Rights" entitles the consumer's (patient's) right "to request provision of the necessary and reliable information about the manufacturer (executor, seller), its work pattern and the goods (works, services) sold [9]", and Article 9 of this Law clearly obligates the manufacturer (executor, seller), upon consumer's request, to provide clear information about itself and the maker (seller) (company name, location (address), work pattern, legal entity state registration number, last name, first name, patronymic (if any), private entrepreneur state registration number) [10].

Since medical services are licensed and medical professionals rendering such should be accredited by the state, under the said law the consumer (patient) must be informed of the type of activity of the manufacturer (executor, seller), the license number and (or) the number of the state accreditation certificate, the duration of this license and (or) certificate, and provided information on the body that issued this license and (or) certificate [11].

Under the Law, the above information shall mandatorily be provided to the consumer of medical services (patient) even if such services are provided outside the permanent location of the medical services provider (at home, in a factory, outdoors and in other conditions) [12].

The medical services provider (medical professional), mandatorily and in a timely manner, provides the consumer (patient) with the necessary and reliable information about the goods (works, services) that enables correct selection of such goods (works, services) [13]

The Law also lists pieces of information that should be conveyed to the patient as consumer of the medical services:

- information about the main consumer properties of goods (works, services);

- information about contraindications relevant in the presence of certain diseases;

- the price in rubles and the goods (work, services) purchase conditions, including post-payment situations, when the goods (work, services) are paid for after a certain time following their transfer (performance, provision) to the consumer, and the full amount payable by the consumer, as well as the payment schedule covering this amount;

- warranty period, if any;

- rules and conditions ensuring effective and safe use of the goods (works, services);

- service life or shelf life of the goods (works), as established by the Russian Federation Law "On Protection of Consumer Rights";

- information about the actions the consumer needs to take once the specified periods are over, and the possible consequences of refusal to take such actions in case the goods (work), when expired, are dangerous for life, health and property of the consumer or become unsuitable for use as intended;

- address (location), company name of the manufacturer (executor, seller), authorized organization or authorized private entrepreneur, importer;

- mandatory confirmation of the conformity of goods (works, services) specified in paragraph 4 of Article 7 of the Russian Federation Law "On Protection of Consumer Rights";

- rules of sale of goods (execution of work, provision of services);

- clear indication of a specific person who will perform the work (provide a service), and information about this person, if it is relevant from the point of view of the nature of work (service) [14].
The Law holds the executor (medical organization) responsible for provision of inappropriate information about the work and/or service offered to the patient.

A medical organization, as a service provider that did not give the patient complete and reliable information about the medical procedure/treatment, is responsible for the faults associated with the said service (work) manifesting after its completion and resulting from the patient not being provided the reliable information in full.

Having discovered deficiencies in the results of the service provided (work performed), the patient has the legal right, at his/her discretion, to demand from the medical organization:

1) gratuitous elimination of the said deficiencies, including complications arising during or after medical intervention;

2) an appropriate price reduction, if the medical service (work) is rendered (performed) for a fee;

3) gratuitous fabrication of another item (for example, a denture) from the same material and of the same quality, or refabrication. In this case, the consumer (patient) shall return the item previously transferred to him/her by the provider;

4) reimbursement of the costs the patient incurred to eliminate the faults of the provided medical service (work performed), such elimination done himself/herself at his/her own expense or with the help of third parties at their expense.

Under Article 29 of the aforementioned Law, a patient, as a consumer, has the right to claim compensation for poor results of both the work performed and the services rendered. This is not an exhaustive list of information a medical professional should provide to a patient before obtaining consent to medical intervention.

Current legislation of the Russian Federation assumes administrative, civil, and criminal liability for medical professionals (medical organizations) if they fail to provide the patient, as a consumer of services, with sufficient, reliable, complete information about the service offered.

Federal Laws lack clear definitions of characteristics of information (complete, sufficient, reliable), which makes conforming to such requirements problematic and enables some patients, i.e., consumers of medical services, to abuse their rights.

\section{CONCLUSIONS}

1. The terms used in federal regulations, i.e., "complete, reliable, sufficient information", do not have clear legal definitions.

2. The vagueness of the list of pieces of information that must be provided to the patient prior to the registration of his/ her consent to medical intervention, such consent relying on complete awareness, creates difficulties in the exercising of the patient's right to personal integrity.

3. It is necessary to legislate the list of pieces of information that medical professionals are obliged to provide to the patient in order to obtain his/her consent based on sufficient and reliable information, relying on the current legislation of the Russian Federation, as applied to court cases of violation of patients' rights in the context of provision of medical services under voluntary and compulsory health insurance policies.

4. Clear legislation that would regulate obtaining patient's consent to medical intervention will enable full realization of the patients' right to personal integrity and also help avoid holding medical professionals (medical organizations) legally liable on formal grounds, in cases not involving harm to the health and life of the patient. 


\section{References}

1. Kartashkin VA, Lukasheva EA. Konvencija o zashhite prav cheloveka i dostoinstva chelovecheskogo sushhestva $\vee$ svjazi $\mathrm{s}$ ispol'zovaniem dostizhenij biologii i mediciny: konvencija o pravah cheloveka i biomedicine. (Ov'edo, 4 aprelja 1997 g.). Mezhdunarodnye akty o pravah cheloveka: Sbornik dokumentov. Izd. NORMA, M., 2002; 742 s. Russian.

2. Dekret VCIK i SNK RSFSR «O professional'noj rabote i pravah medicinskih rabotnikov». Sobr. Uzakonenij i Rasporjazhenij RKP. 1924; 88: 892. Russian.

3. Pishchita AN. Soglasie na medicinskoe vmeshatel'stvo. Medikopravovoj analiz. Juridicheskie standarty. Praktika realizacii. M.: CKB RAN; 2006; 19 s. Russian.

4. Chast' 1 stat'i 20 Federal'nogo zakona ot 21 nojabrja $2011 \mathrm{~g}$. N 323-FZ «Ob osnovah ohrany zdorov'ja grazhdan v Rossijskoj Federacii». SPS «GARANT». Russian.

5. Chast' 1 stat'i 22 Federal'nogo zakona ot 21 nojabrja $2011 \mathrm{~g}$. N 323-FZ «Ob osnovah ohrany zdorov'ja grazhdan v Rossijskoj Federacii». SPS «GARANT». Russian.

6. Stat'ja 79 Federal'nogo zakona ot 21 nojabrja 2011 g. N 323-FZ «Ob osnovah ohrany zdorov'ja grazhdan v Rossijskoj Federacii».

\section{Литература}

1. Карташкин В.А., Лукашева Е.А. Конвенция о защите прав человека и достоинства человеческого существа в связи с использованием достижений биологии и медицины: конвенция о правах человека и биомедицине. (Овьедо, 4 апреля 1997 г.). Международные акты о правах человека: Сборник документов. Изд. НОРМА, М., 2002; 742 с.

2. Декрет ВЦИК и СНК РСФСР «О профессиональной работе и правах медицинских работников». Собр. Узаконений и Распоряжений РКП. 1924; 88: 892.

3. Пищита А.Н. Согласие на медицинское вмешательство. Медико-правовой анализ. Юридические стандарты. Практика реализации. М.: ЦКБ РАН; 2006; 19 с.

4. Часть 1 статьи 20 Федерального закона от 21 ноября 2011 г. N 323-Ф3 «Об основах охраны здоровья граждан в Российской Федерации». СПС «ГАРАНТ».

5. Часть 1 статьи 22 Федерального закона от 21 ноября 2011 г. N 323-Ф3 «Об основах охраны здоровья граждан в Российской Федерации». СПС «ГАРАНТ»

6. Статья 79 Федерального закона от 21 ноября 2011 г. N 323Ф3 «Об основах охраны здоровья граждан в Российской
SPS «GARANT». Russian.

7. Chast' 4 stat'i 70 Federal'nogo zakona ot 21 nojabrja $2011 \mathrm{~g}$ N 323-FZ «Ob osnovah ohrany zdorov'ja grazhdan v Rossijskoj Federaciï. SPS «GARANT». Russian.

8. Postanovlenie Plenuma Verhovnogo Suda Rossijskoj Federacil ot 28 ijunja $2012 \mathrm{~g}$. N $17 \mathrm{~g}$. Moskva «O rassmotrenii sudami grazhdanskih del po sporam o zashhite prav potrebitelej». SPS "GARANT». Russian.

9. Chast' 1 stat'i 8 Zakona RF ot 7 fevralja 1992 g. N 2300-I «O zashhite prav potrebitelej». SPS «GARANT». Russian.

10. Chast' 1.1. stat'i 8 Zakona RF ot 7 fevralja 1992 g. N 2300-I «O zashhite prav potrebitelej». SPS «GARANT». Russian.

11. Chast' 2 stat'i 9 Zakona RF ot 7 fevralja 1992 g. N 2300-I «O zashhite prav potrebitelej». SPS «GARANT». Russian.

12. Chast' 3 stat'i 9 Zakona RF ot 7 fevralja 1992 g. N 2300-I «O zashhite prav potrebitelej». SPS «GARANT». Russian.

13. Chast' 1 stat'i 10 Zakona RF ot 7 fevralja 1992 g. N 2300-I «O zashhite prav potrebitelej». SPS «GARANT». Russian.

14. Chast' 2 stat'i 10 Zakona RF ot 7 fevralja 1992 g. N 2300-I «O zashhite prav potrebitelej». SPS «GARANT». Russian.

Федерации». СПС «ГАРАНТ».

7. Часть 4 статьи 70 Федерального закона от 21 ноября 2011 г. N 323-Ф3 «Об основах охраны здоровья граждан в Российской Федерации». СПС «ГАРАНТ».

8. Постановление Пленума Верховного Суда Российской Федерации от 28 июня 2012 г. N 17 г. Москва «O рассмотрении судами гражданских дел по спорам о защите прав потребителей». СПС «ГАРАНТ».

9. Часть 1 статьи 8 Закона РФ от 7 февраля 1992 г. N 2300-I «O защите прав потребителей». СПС «ГАРАНТ».

10. Часть 1.1. статьи 8 Закона РФ от 7 февраля 1992 г. N 2300-І «О защите прав потребителей». СПС «ГАРАНТ».

11. Часть 2 статьи 9 Закона РФ от 7 февраля 1992 г. N 2300-I «О защите прав потребителей». СПС «ГАРАНТ».

12. Ч Часть 3 статьи 9 Закона РФ от 7 февраля 1992 г. N 2300-I «О защите прав потребителей». СПС «ГАРАНТ».

13. Часть 1 статьи 10 Закона РФ от 7 февраля 1992 г. N 2300-I «О защите прав потребителей». СПС «ГАРАНТ».

14. Часть 2 статьи 10 Закона РФ от 7 февраля 1992 г. N 2300-I «O защите прав потребителей». СПС «ГАРАНТ». 